\title{
Factors that influence household and individual clothing expenditure: A review of research and related literature
}

\author{
Laetitia Viljoen
}

\section{OPSOMMING}

Die doel van die literatuurstudie was eerstens om vas te stel watter faktore huishoudelike en individuele kledinguitgawes beïnvloed. Om die teorie en begrip in hierdie verband uit te bou, is daar tweedens vasgestel hoe dié faktore huishoudelike en individuele kledinguitgawes beïnvloed soos blyk uit beskikbare buitelandse navorsingsartikels. Derdens is die buitelandse navorsingsbevindings met dié van die mees onlangse opname oor huishoudelike uitgawes aan klerasie en skoeisel in Suid-Afrika vergelyk ten einde die toepaslikheid van die betrokke studie te verbreed.

Die vernaamste perspektiewe met betrekking tot die keuse van onafhanklike veranderlikes word gestel en die onafhanklike veranderlikes word sinvol gegroepeer in 'n verwysingsraamwerk van faktore wat aandag verdien wanneer kledinguitgawes bestudeer word. Die faktore sluit die volgende in: inkomste, gesinsamestelling, -grootte en -lewensiklus, sosiale klas, bevolkingsgroep en woonplek. Die vernaamste perspektiewe oor spesifikasies met betrekking tot die onafhanklike veranderlikes word ook bespreek.

Wat die oorsese navorsing betref, is daar spesifieke patrone of neigings te bespeur in die wyse waarop al die faktore, behalwe bevolkingsgroep, kledinguitgawes beïnvloed. Uit die Suid-Afrikaanse opname van huishoudelike uitgawes aan klerasie en skoeisel blyk dit dat soortgelyke patrone te bespeur is, met dié uitsondering dat wat bevolkingsgroep betref, daar ook 'n spesifieke patroon na vore kom.

Dié navorsing kan van waarde wees vir v e r b r u i k e r s t u d e - e n gesinshulpbronbestuurspesialiste, klerevervaardigers en -kleinhandelaars asook vir beleidmakers wat by die vasstelling van geskikte bedrae vir die onderhoud van kinders betrokke is.

- Ms L Viljoen

Departement Consumer Study: Food, Clothing, Housing

University of Stellenbosch

\section{INTRODUCTION}

The relative importance of clothing in the household budget seems to have declined considerably in the past four to five decades. In the United States clothing expenditure accounted for approximately $10 \%$ to $14 \%$ of total consumer expenditure from 1929 to 1952 (Winakor, 1989). Since 1976 clothing expenditure made up only $6 \%$ to $7 \%$ of total consumer expenditure and dropped to an estimated 5,3\% in 1995 (Laughlin, 1996). A lower percentage, but a similar trend pertains to household clothing and footwear expenditure in South Africa. In 1975 the average household expenditure on clothing and footwear was $4,6 \%$ and in 1990 it was $3,89 \%$ of total consumer expenditure (Central Statistical Service, 1990:8; 1975:vii).

Although these proportions reflect competing demands on the family budget, it has to be kept in mind that prices for apparel have risen more slowly than the overall inflation rate (Laughlin, 1996). Contributing factors are the growth of low-priced apparel imports, the increased availability of lowercost clothing over time, the increased durability and decreased cost of synthetic fibres, which obtained an increased share of the market, as well as the functional properties of clothing that have increased more than the price of clothing (Courtless, 1989; 1991; Fan et al, 1996; Laughlin, 1996).

In spite of the above-mentioned trend, clothing, in conjunction with food and shelter, is still considered a basic consumer commodity and a necessary element of human life. Clothing expenditure has been the subject of extensive research. In addition to expanding and strengthening the body of knowledge on individual and household demand systems and decision making, knowledge and a better understanding of the factors that influence clothing expenditure could be of value to family resource management specialists who assist families with their household budgeting. Clothing manufacturers and retailers as well as policy makers involved in setting fair child support payments could also benefit from insight into the factors that influence clothing expenditure (Viljoen, 1997).

\section{PURPOSE}

The purpose of this study of the literature was firstly to determine which factors influence household and individual clothing expenditure, and secondly how 
these factors influence household and individual clothing expenditure as recorded in available overseas research reports. The broad overseas research findings were compared with similar data from the most recent South African survey on household expenditure in order to broaden the applicability of this study.

Traditional and computer literature searches were made for relevant empirical research and related literature. Articles were taken from the following journals in the consumer, clothing, home economics and family study fields: Canadian Home Economics Journal, Clothing and Textiles Research Journal, Consumer Interests Annual, Family Economics Review, Home Economics Research Journal, Journal of Consumer Affairs, Journal of Consumer Research, Journal of Consumer Studies and Home Economics, Journal of Family and Consumer Sciences, and the Journal of Home Economics.

In view of the purpose of this study, the main perspectives on the choice of independent variables are stated briefly with a meaningful grouping of independent variables to serve as a frame of reference for the factors that are to be taken into account when clothing expenditure is studied. The main perspectives on the variable specifications and broad findings pertaining to each factor are discussed, followed by a comparison with applicable data from the most recent survey on household expenditure in South Africa (Central Statistical Service, 1990).

CHOICE OF INDEPENDENT VARIABLES
The selection of independent variables in the available research on clothing expenditure, was mostly based on past research and economic theory. De Weese (1993) mentions that variables are also included to provide an answer to a specific question, i.e. the effect of family structure on clothing expenditure, or to use as a control variable for comparison purposes. In this regard Wagner and Hanna (1983) compared the effectiveness of family life-cycle variables and family composition variables to predict total family clothing expenditure. Norum (1992) examined various age and gender specifications in an effort to identify a categorisation that sufficiently captures the differing effects of children's ages and gender on household clothing expenditure.

While most researchers just list the independent variables, De Weese (1993) divided them into two categories, namely household characteristics and mothers' characteristics. Dardis et al, (1981), Nelson (1989) and Norum (1989) grouped the variables meaningfully under the following headings:

- Income

- Family composition, size and family life cycle

- Social class

- Race

- Location.

Many decisions to buy depend on the lifestyle of the household. Clothing, among other things, is strongly influenced by personal preferences (Central Statistical Service, 1985; Poduska, 1988). Although personal preferences are important and obviously influence clothing expenditure, no research report explicitly deals with this concept. It is therefore not

TABLE 1: FACTORS AND APPLICABLE INDEPENDENT VARIABLES WHICH INFLUENCE CLOTHING EXPENDITURE

\begin{tabular}{|l|l|}
\hline Factor & Independent variables \\
\hline Income & $\begin{array}{l}\text { Household disposable income (income less tax) or pretax } \\
\text { income } \\
\text { Household permanent income (total household consumption } \\
\text { expenditure) }\end{array}$ \\
\hline Family composition, size and family life cycle & $\begin{array}{l}\text { Differing number of age/gender categories } \\
\text { Number of individuals in family } \\
\text { Age of household head } \\
\text { Marital status } \\
\text { Presence of a child younger than six years of age }\end{array}$ \\
\hline Social class & $\begin{array}{l}\text { Educational level/years of education of } \\
\text { head or spouse }\end{array}$ \\
& \multicolumn{1}{c|}{ or } \\
& Ocad and spouse \\
& Employment status \\
\hline Race & $\begin{array}{l}\text { Whites and nonwhites or } \\
\text { Blacks and nonblacks or } \\
\text { Whites and others or } \\
\text { Whites, blacks and others }\end{array}$ \\
\hline
\end{tabular}


included in this discussion. Yang (1996) states that age, gender, family type, social class, marital status and location are included in a clothing expenditure study to account for differences in taste and preference.

As personal preferences are probably jointly accounted for by most of the variables that are usually included in research on clothing expenditure, the above list of headings is proposed as factors to be taken into account when looking into clothing expenditure. These factors and appropriate variables, proposed to serve as a frame of reference for clothing expenditure research, are set out in Table 1 , followed by a discussion on variable specifications and findings.

\section{FACTORS THAT INFLUENCE CLOTHING EXPENDITURE}

\section{Income}

The importance of household income as a determinant of household expenditure has been proven many times in consumer expenditure research (Nelson, 1989). The two income variables measured most often are household disposable income (income less federal, state and local income taxes and other personal taxes) (Lino, 1990; Norum, 1989; Norum, 1992) or pretax income (Courtless et al, 1990; De Weese, 1993; De Weese \& Norton, 1991; Nielsen, 1978), and total household consumption expenditure as a proxy for household permanent income (Fan et al, 1996; Frisbee, 1985; Nelson, 1989; Wagner \& Hanna, 1983). Hager and Bryant (1977) used sources of income of low-income rural families as an income measure. Dardis et al (1981) and Horton and Hafstrom (1985) used both disposable or current income and total household consumption expenditure as income measures.

There is some debate about the more appropriate measure of household income. Researchers propose the use of total consumption expenditure because adequate income data are often unavailable. Recorded income covers only certain types of income, and other types such as income from property and income of subsidiary earners are ignored (Lino, 1990; Nielsen, 1978). The use of total consumption expenditure is also defended on the basis of the permanent income hypothesis: in the short run, families have more control over their expenditure than over their income, and it is a better measure of the household's permanent income than disposable income which may fluctuate over a short period of time (Dardis et al, 1981; Sharpe \& AbelGhany, 1995; Wagner \& Hanna, 1983).

The use of disposable income as a measure has been defended in that there is a possible bias in the use of total consumption expenditure as an independent variable because it includes the dependent variable. It is not a major problem, however, if the dependent variable accounts for only a small proportion of the independent variable, as clothing and services do (Dardis et al, 1981; Wagner \& Hanna, 1983). Using current income as the income measure includes habit formation, which has been found to influence consumption, and it places expenditure into the broader picture of consumption and savings which more closely approximates reality, as opposed to an expenditure that competes only with other expenditures (Lino, 1990). Dardis et al (1981) found total consumption expenditure to be a better explanatory variable over current income, although the results from the two models that were designed designed to explain clothing expenditure were similar.

There is a positive relationship between income and clothing expenditure according to investigations of total disposable income (Abel-Ghany \& Foster, 1982; Dardis et al., 1981; Lino, 1990; Mokhtari, 1992; Wagner \& Hanna, 1983), specific sources of income (Hager \& Bryant, 1977), and total consumption expenditure (Dardis et al, 1981; Nelson, 1989; Frisbee, 1985).

Total expenditure elasticities have mostly been found to be greater than 1,00 whereas disposable income elasticities have been found to be less than 1,00 or less than proportional. An expenditure elasticity reflects the basic relationship between changes in household clothing expenditure and changes in household total consumption expenditure (or income) expressed as a percentage. An expenditure elasticity of 1,00 implies that a $1 \%$ increase in total consumption expenditure (or income) leads to a $1 \%$ increase in clothing expenditure; an expenditure elasticity of 1,25 implies that a $1 \%$ increase in total consumption expenditure (or income) leads to a $1,25 \%$ increase in clothing expenditure, and so on. Values of less than 1,00 are termed inelastic; values equal to 1,00 are termed unitary elastic, and values greater than 1,00 are termed elastic (Frisbee, 1985).

Nielsen (1978) and Fan et al (1996) report evidence that clothing claims an increasing percentage of the income up to a certain income level, with a decrease in the higher-income categories. Sharpe and AbdelGhany (1995) found income elasticity to be greater than 1,00 for clothing in the single-parent group, indicating that clothing was a luxury for this group. The income elasticity for clothing for the two-parent group was very close to 1,00 , indicating that clothing was a necessity for this group.

In the South African survey of household expenditure, income was divided into two categories:

Direct income: The more or less regular income which is depended on for the redemption of current expenditure. Included here are salaries and wages, profit from own businesses, pensions and interest.

Indirect income: This category includes sales and trade-ins of posessions, fringe benefits received from employers, lump sums such as retirement gratuities, 
insurance policies paid out and gifts received.

Only direct income was used in determining the income group per household (Central Statistical Service, 1990).

In the South African survey the average percentage of annual expenditure on clothing and footwer according to income group (direct income) increases up to a certain income level and then decreases for the higher-income categories (Figure 1) (Central Statistical Service, 1990:24)

These findings, namely that clothing claims an increasing percentage of the income up to a certain income level with a decrease in the higher-income categories, correspond with the findings of Nielsen (1978) and Fan et al (1996), and are consistent with the view that households in the lower-income groups regard clothing as a luxury whereas higher-income groups regard it as a necessity (Central Statistical Service, 1985).

To summarise with regard to income as a factor that influences clothing expenditure, the two income variables measured most often are household disposable income or pretax income, and total household consumption expenditure. There is a strong relationship between clothing expenditure and disposable income or total expenditure. The relationship between clothing expenditure and total expenditure is elastic in contrast to the relationship between clothing expenditure and disposable income which is inelastic. In the South African survey only income, ie direct and indirect income, was used. Clothing claims a higher percentage of the income up to a certain income level, and a lower percentage in the higher-income categories.

\section{Family composition, size and family life cycle}

Family life cycle variables are related to family composition variables, in that family composition changes as it progresses through the family life cycle (Wagner \& Hanna, 1983). The effects of stages in the family life cycle and family composition have been measured in various ways. The age of the household head, marital status, and presence of a child younger than six years of age have been investigated alone or in some combination to represent the family life cycle (Dardis et al, 1981; Horton \& Hafstrom, 1985; Lino, 1990; Nielsen, 1978). Family size was also included in these analyses.

Differing numbers of age/gender categories are used to capture the effects of family composition. De Weese (1993) and De Weese and Norton (1991) used seven, Hager and Bryant (1977) used nine, and Nelson (1989) used ten different age/gender categories. Some research studies included family composition as well as family life cycle variables. Norum (1989) used the age of the household head and marital status as a proxy for life cycle and ten age/gender categories to represent family

FIGURE 1: AVERAGE ANNUAL EXPENDITURE ON CLOTHING AND FOOTWEAR ACCORDING TO INCOME GROUP (DIRECT INCOME) (Central Statistical Service, 1990:24) 
composition. Frisbee (1985) used age and gender of the household head and four different age categories for household members. Douthitt and Fedyk (1988) looked into the effect of children on family consumption decisions during different stages in the family life cycle. They compared childless and twochild families and linked them to the age of the male adult to capture the effect of the family life cycle.

Two research projects reported extensive work to clear aspects pertaining to family composition and family life cycle. Wagner and Hanna (1983) compared the effectiveness of traditional family life cycle, revised family life cycle and family composition variables in predicting family clothing expenditure. In economic theory income and family composition are considered the most important variables to influence family expenditure. It was stated that if the family life cycle successfully captures the effects of changes in income and family composition on expenditure, then family life cycle should be a very powerful determinant of expenditure for goods and services. Wagner and Hanna (1983) defined the set of traditional family life cycle variables by the age or employment of the household head, the marital status of the household head, and the age of the youngest child. The set of revised family life cycle variables was defined by the age or employment of the household head, the marital status of the househld head and the age of the oldest child. The family composition variables each represented the number of family members in one of thirteen mutually exclusive age and gender categories. No major differences were found in the predictive ability of the three sets of variables in explaining the variance in family clothing expenditure and that independent of income (as represented by the proxy variable of total consumption expenditure), they have very little predictive value. There is no apparent advantage in increasing the number of family life cycle stages in order to accommodate nontraditional family forms. The basic family composition model was only slightly more successful than the two family life cycle models in explaining the variance in family clothing expenditure, and there is no empirical advantage in accounting for every family member by age and sex.

Norum (1992) examined various age and gender specifications empirically in an effort to identify a categorisation that captures the significance of differing effects of children's ages and gender on household clothing expenditure. Six separate age categorisations were used in different regression estimations. Each model was estimated initially with the age of the children taken into consideration and then re-estimated adding a child's sex. The number of boys and the number of girls in a particular age category were entered as separate variables in the regression equation. The most appropriate age categorisation, which is parsimonious but captures the differing age effects, was identified, namely school age categories. This age categorisation included the ages 0 to 5,6 to 11,12 to 14 and 15 to 17. It was determined that there was insufficient evidence for separating all age categories based on gender. The proposed age categorisation was then evaluated in the light of developmental and economic factor. Among the factors affecting the quantity and types of clothing children need, physiological, motor and social development seems to have the greatest effect. These influences, coupled with economic factors, affect household expenditure on childrens' clothing.

In view of the variables related to family composition and family life cycle, the main findings pertaining to the age of the household head, marital status, presence of children under six, age/gender and family size are briefly as follows:

- A nonlinear relationship was generally found between age of the household head and clothing expenditure (Dardis et al, 1981; Frisbee, 1985; Hager \& Bryant, 1977; Norum, 1989; Yang, 1996). The findings indicate that expenditure on clothing declines as the age of the household head reaches 55 and older. There is no definite pattern prior to this age category and the largest and most significant variation in clothing expenditure occurred in the middle-age categories (25-44). These results may reflect occupational demands of clothing and the accumulation of clothing inventories over the family life cycle, reduced social activities with ageing, and higher expenditure on health and other age-related services (Dardis et al, 1981; Norum, 1989).

- The findings pertaining to marital status are inconsistent. Norum (1989) found that households with a married head spent more on clothing than did households in which the head was not married, whereas Dardis et al, (1981) found that husband-wife families spent less on clothing than other families. Frisbee (1985) found that male-headed households at the mean income level spent less on clothing than femaleheaded households, and that the difference becomes more exaggerated at income levels above the mean. Frisbee (1985) argues that the marital status effect reported by Dardis et al, (1981) probably captured differences between male and female-headed households. In the most recent study Yang (1996) found that marital status was not related to clothing expenditure. The inconsistency was attributed to the "not married" category which includes groups such as "widowed" and "never married" who might behave differently from one another.

- No significant differences were found in the clothing expenditure of households with children under six and other households when total expenditure was used as a proxy for permanent income (Dardis et al, 1981). Similarly children of preschool age and younger did not have a significant effect on overall household clothing expenditure (Norum, 1989).

- The findings of Courtless et al (1990), Nelson

Factors that influence household and individual clothing expenditure: A review of research and related literature 
(1989) and Norum $(1989 ; 1992)$ pertaining to age and gender capture the most important trends. Girls' and boys' mean expenditure exhibits similar patterns by age, with expenditure the highest during infancy and the midteen years, and the lowest at the early preschool ages. The high expenditure for infants relative to other young children is especially surprising, given evidence that children in this age group may also be the heaviest recipients of gifts and hand-me-downs. Further analysis shows that the growing popularity of disposable nappies since the 1960s could be the reason for the high expenditure because they require sizable recurring expenditure (Nelson, 1989).

As the ages of the family members increase, the differences in expenditure due to the sex of the family members become apparent. The results suggest that clothing expenditure on female teenagers is generally higher than on clothing for male teenagers, and that expenditure on adult females' clothing is higher than on adult males'clothing. The apparent drop in expenditure for older teens relative to younger teens could be due to a slowing in the children's physical growth rates and/or to underreporting as children did more of their own shopping and not necessarily made purchases known to the household respondent with whom the interviews were conducted (Nelson, 1989).

- A significant positive relationship was found between clothing expenditure and family size
(Dardis et al, 1981). Nielsen (1978) states that, in general, the percentage of total expenditure accounted for by clothing increased up to a nuclear family size that included three children and then held steady for larger families. This seems to indicate that less is spent on clothing each child in larger families. In the single-parent families studied by Lino (1990) and the femaleheaded families studied by Horton and Hafstrom (1985), family size had no significant effect on clothing expenditure. It may be that much of the children's clothing is handed down in larger single-parent families. The lower clothing expenditure per child in larger families would seem to be primarily due to a decrease in quantity as a certain quality of clothing is required to make handing down possible (Nielsen, 1978). Courtless et al (1990) found that in both singlemother and married-couple families, family size affected expenditure on clothing. As the family size increased, expenditure on children's clothing increased, whereas it decreased for women's and men's apparel.

In the South African survey of household expenditure, family size was determined by the number of household members and did not include visitors or servants. As each family size categry probably includes the whole spectrum of income groups, the average annual empenditure is given in rands in Figure 2.

It is clear from Figure 2 that the findings are similar to those of the overseas researchers. Clothing and

FIGURE 2: $\quad$ AVERAGE ANNUAL EXPENDITURE ON CLOTHING AND FOOTWEAR ACCORDING TO SIZE OF HOUSEHOLD (NUMBER OF PERSONS) (Central Statistical Service, 1990:29) 
footwear expenditure increases up to a family size of four. It then drops and holds more or less steady for larger families (Central Statistical Service, 1990:29).

To summarise: A variety of variables are used to measure the effect of the factor family composition, size and family life cycle on clothing expenditure. With regard to the family life cycle, it has generally been found that there is a nonlinear relationship between the age of the household head and the clothing expenditure of the household. Expenditure on clothing declines as the age of the household head reaches 55 and older. The findings pertaining to marital status and clothing expenditure were inconsistent, and no significant differences were found in the clothing expenditure of households with children under six years of age and other households.

With regard to family composition it was found that girls' and boys' mean clothing expenditure exhibits similar patterns by age, with expenditure the highest at infancy and in the mid-teen years and lowest at the early preschool ages. Clothing expenditure for female teenagers and adult females is higher than for their male counterparts. A positive relationship exists between clothing expenditure and family size. However, in large families less is spent on clothing per person.

In the South African survey family size was determined by the number of members per household and the results more or less corresponded with the findings of the overseas studies.

\section{Social class}

Educational level or years of education and occupation or employment status of the head of the household, spouse or head and spouse have been investigated alone or in some combination to represent social class. Educational level is mostly described as some grade school, some high school, high-school graduate, some college and college graduate. Occupation is mostly described in terms of blue and white-collar occupations as well as nonemployed, and employment status is described in terms of employed or nonemployed.

Occupation and education of the household head and the occupational status of the wife or spouse were studied as social class variables by Dardis et al (1981), Norum (1989; 1992) and Yang (1996). De Weese (1993) and De Weese and Norton (1991) used the mother or wife's education level and occupation, and Horton and Hafstrom (1985) used the education and employment status of the women. Lino (1990) used the education and employment status of the head in single-parent families. Courtless et al (1990) used education of the household head, and Abdel-Ghany and Foster (1982) and Hager and Bryant (1977) used the wife's education. Frisbee (1985) included the years of education of the household head and the employment status of the spouse, and Nelson (1989) included the education and occupations of both parents.

The findings are broadly as follows: Higher educational levels are associated with higher expenditure for clothing (Abdel-Ghany \& Foster, 1982; Courtless et al, 1990; Dardis et al, 1981; Frisbee, 1985; Hager \& Bryant 1977; De Weese, 1993). There was one exception in De Weese's (1993) findings, however. It was found that the expenditure for infants in two-parent households was higher when the mother had no high-school education than when she was a high-school graduate. De Weese and Norton (1991) found that the college attendance and/or college graduation of the wives in two-parent families had a positive impact on all the clothing categories except for girls, where the mother's education was not significant. Level of education in Horton and Hafstrom's (1985) study had a positive effect on family clothing expenditure, but education of the male household heads in two-parent families did not. Nelson (1989) found that mothers with less than a high-school education seemed to reduce expenditure on girls' clothing and some with a college education seemed to increase expenditure on herself and the father. College education was not associated with an increase in expenditure on the father None of the coefficients for the father's education was statistically significant (Nelson, 1989). Although the positive effect of education on clothing could result from differences in tastes and preferences, it could also reflect the fact that persons with a higher education would be more likely to hold professional positions, for which a more expensive wardrobe would be needed (Abdel-Ghany \& Foster, 1982).

It was furthermore found that in the case of whitecollar occupations and employment of women, the mother/married woman generally increased her household clothing expenditure (Dardis et al, 1981; De Weese \& Norton, 1991; Frisbee, 1985; Hager Bryant, 1977; Norum, 1989; Yang, 1996). Norum (1989) found higher family clothing expenditure among white-collar wives than among nonemployed wives, but lower clothing expenditure among bluecollar wives than among nonemployed wives. Norum (1989) states that uniforms provided to blue-collar employers and the fact that blue-collar workers wear casual, inexpensive clothing which could even be older clothes appropriated for work, could have played a role in these results.

De Weese (1993) found that white-collar women, whether married or single parents, spent significantly more on their own clothing than comparable nonemployed women. Nelson's (1989) study indicated that white-collar or professional wives spent the most on clothing, and that blue-collar wives spent less than or as much as nonemployed wives on clothing. De Weese and Norton (1991) found that the wife's occupation affected expenditure on clothing for other family members in addition to her own. Expenditure for boys in Nelson's (1989) study increased when the mothers held blue-collar, parttime jobs. The employed single parents in Lino's 
(1990) study recorded significantly higher expenditure for clothing than did the nonemployed. Horton and Hafstrom (1985) found that the employment status of female-headed households was not significant. Generally, no significant white-collar/blue-collar effects were found with respect to males and fathers.

In the South African survey of household expenditure the occupational group of a household was based on the occupation, industry and work status of its head according to the classification set out in Table 2 . In occordance with the overseas research, the annual average expenditure is given in rands in Figure 3.

It is clear from Figure 3 that more is spent on clothing and footwear in households where the heads are workers for their own accounts, than in households where the heads are salary and wage earners in professional, technical, administrative and managerial occupations. Households with heads in clinical and sales occupations spend less on clothing than the households mentioned above but more than households with heads in production, transport and service occupations. Clothing and footwear expenditure is the lowest in households where the heads are pensioners or economically inactive (Central Statistical Service, 1990:34).

Occupations in South Africa are not commonly described in terms of blue and white-collar occupations. The results of the overseas studies and the South African survey are quite similar to the extent that persons in white-collar occupations are comparable to workers for their own accounts and people in professional, technical, administrative and managerial occupations, and persons in blue-collar occupations are comparable to people in production, transport and service occupations. It must be noted, however, that in the overseas studies the occupations of women (mothers, wives) had specific effects on clothing expenditure whereas no specific white-collar/ blue-collar effects were found with respect to males and fathers. The occupational group of the household head was taken into account in the South African survey.

To summarise: The variables used to capture the influence of social class on clothing expenditure include educational level, years of education, and occupation or employment status of the head of the household, spouse or head and spouse. Higher educational levels were associated with higher clothing expenditure. White-collar occupations and employment of women generally increased household clothing expenditure. In the South African survey the occupational groups of household heads were taken into account and the findings were similar to those of the overseas research, even though the results probably pertain mostly to males.

\section{Race}

Where race was included as an independent variable, two categories were generally reported, namely whites and nonwhites (De Weese, 1993; De Weese \& Norton, 1991; Lino, 1990; Nelson, 1989; Norum 1989), or blacks and nonblacks (Dardis et al, 1981; Horton \& Hafstrom, 1985). Norum (1992) used whites and others as the two categories, and Courtless et al (1990) mentioned blacks, whites and other races in

\section{FIGURE 3: $\quad$ AVERAGE ANNUAL EXPENDITURE ON CLOTHING AND FOOTWEAR ACCORDING TO} OCCUPATIONAL GROUP OF HEAD (Central Statistical Service, 1990: 29) 
TABLE 2:

CLASSIFICATION OF OCCUPATIONAL GROUP OF HOUSEHOLD ACCORDING TO OCCUPATION, INDUSTRY AND WORK STATUS OF ITS HEAD (Central Statistical

Service,

\begin{tabular}{|c|c|c|c|}
\hline & Work status & Occupation & Industry \\
\hline $\begin{array}{l}\text { Salary and wage } \\
\text { earners }\end{array}$ & Employee & & \\
\hline A & & $\begin{array}{l}\text { Professional technical, } \\
\text { administrative and } \\
\text { managerial }\end{array}$ & All \\
\hline B & & Clerical and sales & All \\
\hline C & & $\begin{array}{l}\text { Production, transport, } \\
\text { service, etc. }\end{array}$ & Manufacturing \\
\hline D & & $\begin{array}{l}\text { Production, transport, } \\
\text { service, etc. }\end{array}$ & All except manufacturing \\
\hline Total & & All & All \\
\hline $\begin{array}{l}\text { Workers for own } \\
\text { account }\end{array}$ & Employer & All & All \\
\hline Pensioners & $\begin{array}{l}\text { Not economically } \\
\text { active }\end{array}$ & Retired persons & Not economically active \\
\hline Other & $\begin{array}{l}\text { Not economically } \\
\text { active }\end{array}$ & $\begin{array}{l}\text { Other persons not } \\
\text { economically active } \\
\text { (students, etc.) }\end{array}$ & Not economically active \\
\hline
\end{tabular}

their findings.

Dardis et al (1981) found that households headed by nonblacks spent a lower percentage of their income on clothing than households headed by blacks. They attributed this finding to clothing being compensatory consumption goods. They stated that the relative importance of clothing for blacks may decline in future because of increased job opportunities and a greater range of consumption activities. Based on the findings of De Weese (1993), De Weese and Norton (1991), Lino (1990), Norum (1989) and Yang (1996), it may appear that the forecasts of Dardis et al (1981) were realised as no significant differences were found between the races in these studies. Differences in clothing expenditure among races in Courless et als (1990) study were not pronounced. One might have to conclude that the influence of race in clothing expenditure studies is mixed, as the earlier study of Hager and Bryant (1977) found that race was not significant. A study which was conducted in later years showed smilar results as Dardis et als research (1981). Horton and Hafstrom (1985) found that both nonblack two-parent and female-headed families spent a lower percentage of their income on clothing than comparable black families.

In the South African survey of household expenditure the percentages of income spent on clothing and foorwear for the four main population groups of the country, namely whites, coloureds, Asians and blacks, are given in Figure 4. It is clear from Figure 4 that whites, coloureds and Asians spend a smaller percentage of their incomes on clothing and footwear than the black population group (Central Statistical Services, 1990:78-79).

As the influence of race on clothing expenditure in the overseas research does not reveal a definite pattern, the results differ from the South African data. The South African findings do however resemble those of Dardis et al (1981), pertaining to nonblacks (Dardis et al, 1981) and whites (Central Statistical Services, 1990:78-79).

To summarise: The variables taken into account to determine the influence of race on clothing expenditure are whites and nonwhites or blacks and nonblacks as well as other races. The influence of race on clothing expenditure in overseas studies was mixed. In the South African survey the four main population groups of the country were taken into account, namely whites, coloureds, Asians and blacks. Whites, coloureds and Asians were found to spend a smaller percentage of their incomes on clothing and footwear than the other population group.

\section{Location}

Factors that influence household and individual clothing expenditure: A review of research and related literature 


\section{FIGURE 4: $\quad$ AVERAGE ANNUAL EXPENDITURE ON CLOTHING AND FOOTWEAR ACCORDING TO POPULATION GROUP (Central Statistical Service, 1990:34)}

Both the geographic region of the country and the location of the residence, whether urban or rural, have been explored, or either one of the two variables, to represent the location of the household. Regional differences were generally found in all the studies which included this variable (Abdel-Ghany \& Foster, 1982; Courtless et al, 1990; Dardis et al, 1981; Frisbee, 1985; Nielsen, 1978; Norum 1989). With the exception of Lino's (1990) sample of singleparent families, where urban/rural differences did not affect clothing expenditure, it was generally found that households in urban locations spent more on clothing than households in rural locations (Courtless et al, 1990; Dardis et al, 1981; De Weese, 1993; Frisbee, 1985; Nielsen, 1978). Nelson (1989) found that the urban/rural difference was mainly accounted for in expenditure on clothing for girls. They therefore suggest that variations in household expenditure by location could primarily be due to variation in children's and especially girls' expenditure as they were lower in the nonurban than in the urban areas.

The results of the location variables and what they may reflect are interesting. Price differences across the regions of a country and between urban and rural areas, to the extent that they exist, are responsible in part for differences in expenditure by households with different locational characteristics. The differences may reflect the fact that climatic differences influence clothing expenditure. Frisbee (1985) found total clothing expenditure to be lower in regions with relatively benign climates. Location differences also reflect different consumer values. Relative to other goods and services and relative to other individuals, consumers in some regions of a country may prefer to allocate their incomes more strongly to clothing (Frisbee, 1985; Nielsen, 1978). Although they are less easily identifiable, such things as differences in fashion consciousness and style preferences should not be ignored. Nielsen (1978) states that these variables are correlated among themselves and are also interconneced in terms of their influence when a particular city is considered.

The main purpose of the South African survey was to determine the average expenditure patterns in the urban areas of the country, to form a basis for the determination of the "basket" of consumer goods and services to be used for the calculation of the consumer price index. Therefore, pertaining to location, only urban areas were taken into account. In Figure 5 the annual average clothing expenditure in rands if given for twelve different urban areas in the country.

It is apparant from Figure 5 that regional differences do exist, as in the overseas studies. Two urban areas of the Gauteng Province, namely Pretoria and the Witwatersrand, recorded the highest clothing and footwear expenditure, whereas Cape Town had the lowest. The tropical and probably benign climate of Durban and Pietermartizburg could be the reason for the lower clothing and footwear expenditure in these two urban areas. Cape Town, Port Elizabeth, Kimberley and the Vaal Triangle, which also recorded low expenditures for clothing and footwear compared to Pretoria and the Witwatersrand, have climates which are quite extreme.

To summarise: Pertaining to effect of the location factor, the variables geographic region of the country and location of the residence, whether urban or rural, were taken into account in overseas studies. The South African survey was conducted in urban areas 


\section{FIGURE 5: AVERAGE ANNUAL EXPENDITURE ON CLOTHING AND FOOTWEAR ACCORDING TO URBAN AREA (Central Statistical Service, 1990: 78-79)}

only. Regional differences were generally found in both the overseas studies and in the South African survey. The overseas studies also found that households in urban areas spent more on clothing than households in rural areas.

\section{SUMMARY AND CONCLUDING REMARKS}

The relative importance of clothing in the household budget seems to have declined during the past four to five decades. An important explanation for the decline in clothing expenditure as a share of total expenditure is that prices of apparel have risen more slowly than the overall inflation rate. It could however also be that clothing is becoming more of a necessity and less of a luxury than the existing theories have recognised. Other factors such as a more casual lifestyle and casual fashions have probably also played an important role. It is possible that the introduction of new commodities such as electronic goods could also be a reason for the drop in clothing expenditure.

The purpose of this study was firstly to determine which factors influence household and individual clothing expenditure. From the study of overseas research and the related literature as well as the South African survey of household expenditure, it is clear that the most important factors to be taken into account when researching clothing expenditure include the following:

- Income

- Family composition, size and family lifecycle

\author{
- Social class \\ - Race and \\ - Location
}

In order to build and expand the body of knowledge pertaining to clothing expenditure, it was secondly determined how these factors influence clothing expenditure. Certain broad patterns can be identified in how the different factors influence clothing expenditure:

Pertaining to income, there is a strong relationship between clothing expenditure and disposable income and total expenditure. The relationship between clothing expenditure and total expenditure is elastic whereas the relationship between clothing expenditure and disposable income is inelastic. According to the South African survey of household expenditure, clothing claims a higher percentage of income up to a certain income level and a lower percentage of income in the higher-income categories.

A nonlinear relationship has generally been found between the age of the household head and clothing expenditure. As the household head reaches the age of 55 and older, expenditure on clothing declines. The findings pertaining to marital status and clothing expenditure were inconsistent and no significant differences were found between households with and without children under the age of six years.

With regard to family composition, girls' and boys' clothing expenditure exhibits similar patterns by age, 
being the highest at infancy and during the mid-teen years. Clothing expenditure for female teens and adults is generally higher than for males. A positive relationship exists between clothing expenditure and family size, but less is spent on clothing in larger families. In this regard the South African findings were more or less similar to those of the overseas studies.

Pertaining to social class, higher educational levels are commonly associated with a higher clothing expenditure. White-collar occupations of women and employment of women were associated with higher clothing expenditure -- findings which more or less corresponded with the findings of the South African survey of household expenditure.

In contrast with the South African survey, where whites and Asians spent a smaller percentage of their income on clothing and footwear than blacks, the influence of race on clothing expenditure in overseas studies was mixed.

With regard to location it is clear that there are differences in expenditure on clothing in the different regions of a country. Households in urban areas spend more on clothing than households in rural areas.

A study of this nature could have practical applications, and could be of value to family resource management specialists who have to help evaluate clothing needs and estimate guidelines for particular family and income structures. The results could also be of value to clothing manufacturers and retailers. Expenditure on clothing could for instance decrease in the long term as the number of elderly people (above the age of 65) increases. The same could apply to the unemployment rate in a country or specific area.

This study would also be of interest to home economists and consumer studies specialists who examine and compare the impact of the abovementioned factors on food, clothing and housing expenditure. Greater insight into changing patterns of clothing expenditure could perhaps be gained if the impact of the above factors on specific clothing categories such as men's wear, sportswear or leisure wear were studied.

\section{REFERENCES}

ABDEL-GHANY, M \& FOSTER, AC (1982): Impact of income and wife's education on family consumption expenditures. J Consum Stud Home Econ 6(1):21-28. CENTRAL STATISTICAL SERVICE (1975): Detailed expenditure according to occupational group, household size and income group. Report No. 01-11-02 (1975). Pretoria.

CENTRAL STATISTICAL SERVICE (1985): Detailed expenditure according to occupational group, household size and income group. Report No. 01-11-02 (1985). Pretoria.

CENTRAL STATISTICAL SERVICE (1990): Survey of household expenditure, $1990 . \quad$ Report No. 01-11-01. Pretoria.

COURTLESS, JC (1989): Recent trends in clothing and textiles. Fam Econ Rev 2(1):8-13.
COURTLESS, JC (1991): Developments in apparel, textiles and fibers affecting the consumer. Fam Econ Rev 4(2):27. COURTLESS, JC, SCHWENK, FN \& NEAL, EG (1990): Clothing expenditures of single-parent households. Paper presented at Annual Agricultural Outlook Conference. United States Development of Agriculture. Washington, DC. DARDIS, R, DERRICK, F \& LEHFELD (1981): Clothing demand in the United States: a cross-sectional analysis. Home Econ Res J 10(2):212-223.

DE WEESE, G (1993): Female-headed households: impact of family structure on quarterly expenditures for clothing. Home Econ Res J 22(1):39-57.

DE WEESE, G \& NORTON, M (1991): Impact of married women's employment and individual household member expenditures for clothing. J Consum Aff 25(2):235-257.

DOUTHITT, RA \& FEDYK, JM (1988): The influence of children on family life cycle spending behavior: theory and applications. J Consum Aff 22(2):220-248

FAN, JX, LEE, J \& HANNA, S (1996): Household expenditure on apparel: a complete demand system approach. Consum Interests Annual 42:173-180.

FRISBEE, WR (1985): Economic analysis of household clothing expenditures. Canadian Home Econ J 35(4):201206.

HAGER, CJ \& BRYANT, K (1977): Clothing expenditures of low income rural families. J Consum Aff 11(2):127-132. HORTON, SE \& HAFSTROM, JL (1985): Income elasticities for selected consumption categories: comparison of single female-headed and two-parent families. Home Econ Res J 13(3):292-303.

LAUGHLIN, J (1996): Textiles and clothing researchers' response to Garbarino's "Socially Toxic Environment". J Fam Consum Sciences 88(1):60-63.

LINO, M (1990): Factors affecting expenditures of singleparent households. Home Econ Res J 18(3):191-201.

MOKHTARI, M (1992): An alternative model of US clothing expenditures: application of cointegration techniques. J Consum Aff 26(2):305.

NELSON, JA (1989): Individual consumption within the household: a study of expenditures on clothing. J Consum Aff 23(1):21-44.

NIELSEN, J (1978): Clothing consumption in Canada. Canadian Home Econ J 28(2):120-130.

NORUM, PS (1989): Economic analysis of quarterly household expenditures on apparel. Home Econ Res J 17 (3):228-240

NORUM, PS (1992): A reassessment of age and gender specifications on household expenditures: development of age category guidelines for determining clothing allotments. Cloth Text Res J 11(1):45-54.

PODUSKA, B (1988): A comparative study of family budgets: an international perspective. J Home Econ 80 (2):16-23.

SHARPE, DL \& ABDEL-GHANY, M (1995): Spending patterns of lone parents and two-parent Canadian families. J Consum Stud Home Econ 19(3):289-298.

VILJOEN, L (1997): Household and individual clothing expenditure: a review of the research and related literature. $J$ Dietet Home Econ 25(2):126-130.

WAGNER, J \& HANNA, S (1983): The effectiveness of family life cycle variables in consumer expenditure research. J Consum Res 10:281-291.

WINAKOR, G (1989): The decline in expenditures for clothing relative to total consumer expenditures. Home Econ Res J 17(3):195-215.

YANG, Y (1996): Income elasticities for clothing expenditure: a comparison among different occupational groups. Consum Interests Annual 42:447-452. 